\title{
A COMPARISON OF CADMIUM CONCENTRATIONS IN TISSUES OF DIFFERENT CATEGORIES OF CATTLE
}

\author{
A PECHOVÁ', J. ILLEK', L. PAVLATA', M. ŚINDELÁR' ', D. HORKÝ'
}

${ }^{1}$ Clinic of Diseases of Ruminants, Faculty of Veterinary Medicine, University of Veterinary and Pharmaceutical Sciences, Brno, ? Institute of Histology and Embryology, Faculty of Medicine, Masaryk University, Brno, Czech Republic

Received March 23, 1998

Accepted June 5, 1998

\begin{abstract}
Pechová A., J. Illek, L. Pavlata, M. Šindelář D. Horký : A Comparison of Cadmium Concentrations in Tissues of Different Categories of Cattle. Acta vet. Brno 1998, 67: 103-107.

Concentrations of cadmium in selected tissues collected from various categories of Black Pied cattle were compared. All the animals, including 7 cows aged 3 to 11 years, four heifers aged 26 to 28 months, 14 bulls aged 24 to 26 months, and 7 calves aged 4 to 6 months, were kept at a single farm. Samples of hepatic, renal, myocardial, and diaphragmatic tissues were collected after slaughter. The samples were mineralized using the microwave digestion technique and cadmium was determined by the ETA-A.AS method. The following mean concentrations $\left(\mu \mathrm{g} \cdot \mathrm{kg}^{-1} \pm \mathrm{SD}\right.$ ) were found in individual tissues of cows, bulls, heifers, and calves: renal $-647.8 \pm 384.9,317.43$ $\pm 101.24,366.0 \pm 79.24$. and $133.74 \pm 116.71$. respectively: hepatic $-166.36 \pm 59.13,1+4.1 \pm 24.4$, $159.45 \pm 72.3$, and $46.2 \pm 28.35$, respectively: myocardial $-1.94 \pm 0.93,1.88 \pm 0.8,1.35 \pm 0.9$, and $1.61 \pm 1.35$, respectively; diaphragmatic $-1.43 \pm 0.74,0.79 \pm 0.6,1.27 \pm 0.89$. and $1.08 \pm 0.98$, respectively. Highly significant differences were found between calves and any other category in the concentration of cadmium in liver and between calves and bulls or heifers in the concentration of cadmium in kidneys. The latter difference between calves and cows was significant. A highly significant correlation between age and concentration of cadmium in renal tissue was confirmed in cows $(r=0.943)$.
\end{abstract}

Cadmium, cattle, kidneys, liver, myocardium, diaphragm, age

The occurrence of cadmium as an environmental pollutant and its toxic and cumulative effect in the food chain have been monitored for many years. Cadmium is an agent inducing oxidative stress manifested in liver tissue by increased peroxidation of lipids, decrease of glutathione, and damage to hepatocytary DNA. There exists evidence on many adverse effects on live organisms, such as chromosomal aberrations, embryonic malformations, renal dysfunction, testicular necroses, and interstitial pneumonia (Bencko et al. 1984; Horký et al. 1998). Intensive studies of metabolism of cadmium in context with its dynamics in the environment (Cibulk a 1986; Andronie et al. 1994) were motivated by the noxious effects on health. Kottferová and Koreneková (1995), who analysed tissues of animals slaughtered in an East Slovakian industrial area in 1991-1992, demonstrated concentrations of cadmium, nickel and copper exceeding the current hygienic standards in $12.5 \%$ dairy cows. The following concentrations of cadmium $\left(\mu \mathrm{g} \mathrm{kg}^{-1}\right.$; hygienic standards are given in parentheses) were found by Drápal et al (1997) in cattle in 1996: beef -8 (50), liver - 84 (500), kidneys - 316 (1000). Although the current level of

\footnotetext{
Address for correspondence:

MVDr. Alena Pechová. CSc

Clinic of Ruminant Diseases

University of Veterinary and Pharmaceutical Sciences

Palackéhó 1-3

$612+2$ Brno. Czech Republic
} 
contamination of cattle by cadmium is apparently low in the Czech Republic, values exceeding the hygienic standard are found in some herds. Therefore, studies of metabolism of this element deserve further attention.

The objective of our investigations was to compare concentrations of cadmium in selected tissues collected from different categories of cattle and to assess the dependence between age and accumulation of cadmium in the organism.

\section{Materials and Methods}

The investigations were done in a herd of Black Pied cattle at a farm in the Bohemian-Moravian Highlands, which is a region with a low burden of industrial pollutants. The set of animals under study included 7 culled cows aged 2.5 to 11 years, 7 culled heifers aged 26 to 28 months, and 14 bulls aged 24 to 26 months. The set was completed with 7 calves aged 4 to 6 months used previously as a control group within studies of supplementation of rations with trace elements. Samples of liver (lobus caudatus), kidneys (cortex renis), myocardium (apex cordis) and diaphragm (pars costalis) were collected after slaughter, immediately frozen and kept at $-20^{\circ} \mathrm{C}$ until analysed. Cadmium was determined in samples mineralized by the microwave digestion technique (MILESTONE) using the ETA AAS method and the apparatus SOLAR 939 (UNICAM), and expressed in $\mathrm{g}^{\cdot \mathrm{kg}^{-1}}$ wet tissue.

The results were processed by variance analysis ANOVA, Student's t-test and correlation analysis using the EXCEL Version 6.0 software.

\section{Results and Discussion}

Mean concentrations of cadmium in selected tissues collected from different categories of cattle are given in Figs 1 through 4. Like other authors (Cibulk a 1986) we found the highest cumulation in kidneys, where the concentrations ranged between 38.65 and 1204 $\mu \mathrm{g} \cdot \mathrm{kg}^{-1}$. As far as the dependence on age is concerned, the lowest mean value was found in calves $\left(133.74 \pm 116.7 \mu \mathrm{g} \cdot \mathrm{kg}^{-1}\right)$, followed by bulls and heifers $(317.43 \pm 101.24$ and 366.02 $\pm 79.24 \mu \mathrm{g} \cdot \mathrm{kg}^{-1}$, respectively) and cows $\left(647.8 \pm 384.93 \mu \mathrm{g} \cdot \mathrm{kg}^{-1}\right)$. The differences between calves and bulls and between calves and heifers were highly significant and those between calves and cows were significant. The concentration of cadmium in kidneys was highly dependent on age. Detailed investigations of this relationship were done in a group of heifers and cows including dairy cows aged 2 to 11 years. While in the heifers, aged 2 years, the lowest concentration was $288.87 \mu \mathrm{g} \mathrm{kg}^{-1}$, in the oldest cow (11 years) the concentration reached $1204.1 \mu \mathrm{g} \mathrm{kg}^{-1}$. The correlation between age and the concentration of cadmium in renal tissue was highly significant $(r=0.943)$. Our results have confirmed those of other

Table 1

Statistical significance of differences in concentration of cadmium between individual categories of cattle

\begin{tabular}{|l|c|c|c|c|}
\hline & Diaphragm & Myocardium & Liver & Kidney \\
\hline Cows: Bulls & - & - & - & - \\
Cows: Heifers & - & - & - & - \\
Cows: Calves & - & - & $* *$ & $*$ \\
Bulls: Heifers & - & - & - & - \\
Bulls: Calves & - & - & $* *$ & $* *$ \\
Heifers: Calves & - & - & $* *$ & $* *$ \\
\hline
\end{tabular}


authors (Antoniou 1991), who also demonstrated a close correlation between age and the amount of cadmium cumulated in tissues. The values obtained in our experiments also correspond to results of analyses carried out by Zmudski and Szkoda (1995) in Poland (989 $\left.\mu \mathrm{g} \cdot \mathrm{kg}^{-1}\right)$, Doganoc (1996) in Slovenia $\left(373 \mu \mathrm{g} \cdot \mathrm{kg}^{-1}\right)$, Arranha et al. (1994) in Brasil $\left(230 \mu \mathrm{g}^{\cdot} \mathrm{kg}^{-1}\right)$, and Morcombe et al. (1994) in Australia $\left(310 \mu \mathrm{g} \cdot \mathrm{kg}^{-1}\right)$.

Cadmium cumulates also in liver tissue. The concentrations found in individual animals ranged from 12.3 to $260.89 \mu \mathrm{g} \cdot \mathrm{kg}^{-1}$. The differences between values found in calves and those found in any other category were highly significant, but the differences among individual categories were less marked ( 166.36 $\pm 59.13,159.45 \pm 72.30$, and 144.10 $\pm 24.40 \mu \mathrm{g}^{\mathrm{kg}} \mathrm{g}^{-1}$ in cows, heifers and bulls, respectively, and $46.2 \pm 28.35$ $\mu \mathrm{g} \cdot \mathrm{kg}^{-1}$ in calves). The correlation between age of cows and the concentration of cadmium in hepatic tissue was nonsignificant $(\mathrm{r}=0.543)$. The concentration of cadmium in hepatic tissue of cows increased with age, but no marked differences were found among cows, bulls, and heifers. The concentrations of cadmium in hepatic tissue of bulls, heifers and cows were almost the same, but a highly significant difference was demonstrated between calves and any of the three categories. This may have been due to differences in rations fed to the individual categories and hence different intake of cadmium. However, a certain role may be played by the fact that liver is the major organ of the initial step of cadmium metabolism consisting in its detoxification and production of metallothionein. Cadmium is
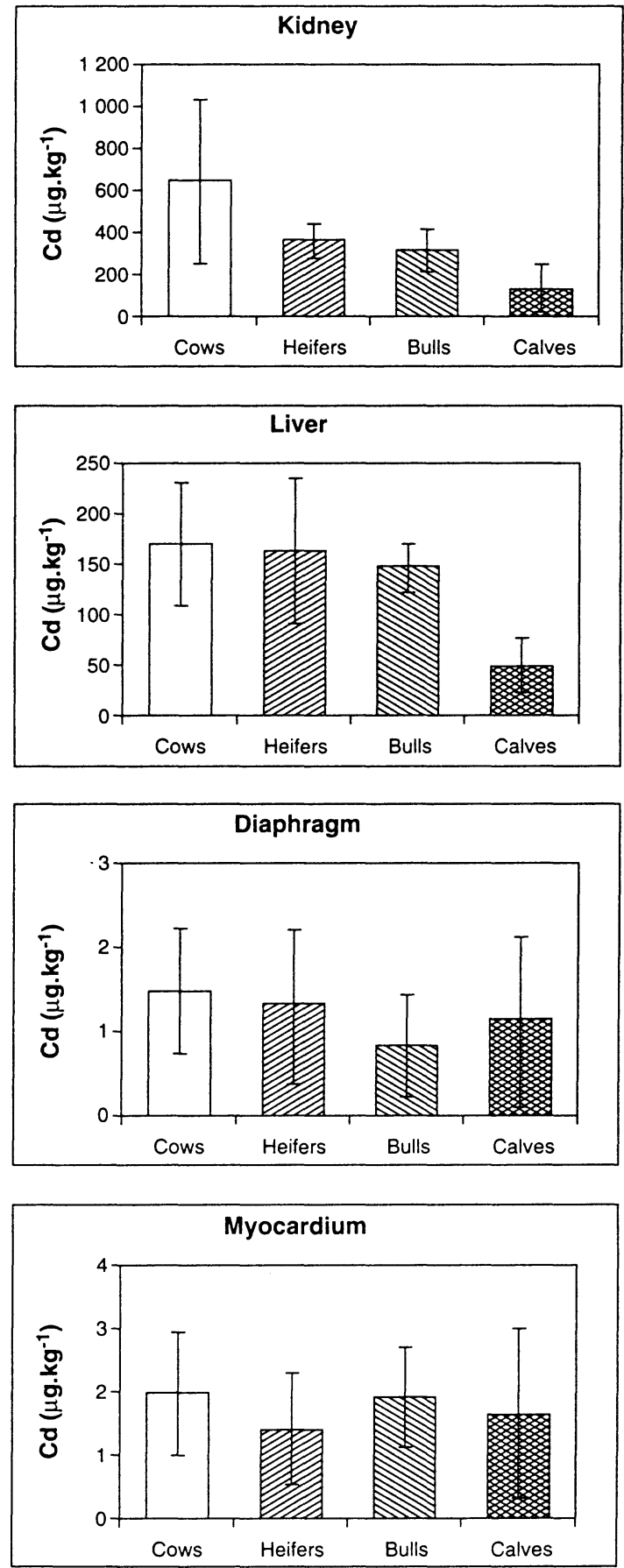

Figs. 1 through 4: Concentrations of cadmium in selected tissues of individual categories of cattle (mean \pm SD) 
released from the liver with bile (Frazier 1977). The high metabolic output of liver in dairy cows during lactation can then influence the concentration of cadmium in the liver and, to a certain extent, increase its clearance from this organ. This might be an explanation for the relatively low concentrations of hepatic cadmium in young cows. The values found in 2.5and 3-year-old cows (106.1 and $115.8 \mu \mathrm{g} \cdot \mathrm{kg}^{-1}$, respectively) were lower than the results obtained in heifers and bulls that were younger by approximately six months. The effect of hepatic functions on the excretion of cadmium were confirmed by Nomiyama and Nomiyama (1993) who observed an improvement of the state of health of rabbits after the treatment of $\mathrm{Cd}$-induced hepatic damage. Another possible explanation is that dairy cows receive higher doses of minerals known for their interactions with cadmium, such as calcium, zinc, copper, iron, and selenium (Illek and Doč ekalo vá 1993; Ohta et al. 1993; Andersen and Nielsen 1994).

The very low concentrations of cadmium in myocardium and diaphragm, that did not exceed $4 \mu \mathrm{g} \cdot \mathrm{kg}^{-1}$. indicate that this element cumulates in muscular tissues only if the intake is high. Our investigations were done in a region with a low burden of industrial pollutants and no increase in the concentration of cadmium in muscular tissue was observed even in a 11-year-old cow. Neither differences among the categories, nor correlations between age and the concentration of cadmium in myocardium ( $\mathrm{r}=0.459$ ) or diaphragmatic muscles $(\mathrm{r}=0.184)$ were significant. Comparable values were reported by Drápal et al. (1997) who found values of 2 to $10 \mu \mathrm{g} \cdot \mathrm{kg}^{-1}, 11$ to $50 \mu \mathrm{g} \cdot \mathrm{kg}^{-1}$, and 100 to $300 \mu \mathrm{g} \cdot \mathrm{kg}^{-1}$ in $85.7 \%$, $13.6 \%$, and $0.7 \%$ of adult cattle, respectively. Our results have confirmed the finding of Neathery and Miller (1975) that muscular tissue, representing a major part of body mass, is well protected against cumulation of cadmium and that its concentration is not age-dependent unless the intake is markedly increased. Underwood (1977) observed a marked increase in the concentration of cadmium in muscles only when the diet contained $450 \mathrm{ppm} \mathrm{Cd}$.

\section{Srovnání koncentrace Cd ve tkáních u různých kategorií skotu}

Cílem práce bylo srovnání koncentrace $C d$ ve vybraných tkáních u různých kategorií skotu černostrakatého plemene. V̌sechna zvírata pocházela z jednoho zemědělského podniku. Bylo odporaženo 7 krav ve stáři 3 - 11 let, 4 jalovice ve stáři 26 - 28 měsícủ, 14 býkủ ve stáŕi $24-26$ měsíců a 7 telat ve stáři 4 - 6 měsícủ. Po odporažení na jatkách byly odebrány vzorky jater, ledvin, myokardu a bránice. Vzorky jednotlivých tkání byly mineralizovány mokrou cestou mikrovlnnou digesční technikou, koncentrace $\mathrm{Cd}$ byla stanovena metodou ETA-AAS. V jednotlivých analyzovaných tkáních byly zjištěny následující průměrné koncentrace $( \pm \mathrm{SD}) \mathrm{Cd} v \mu \mathrm{g} \cdot \mathrm{kg}^{-1}$ čerstvé tkáně (postupně krávy, býci, jalovice, telata) ledviny $(647,8 \pm 384,9 ; 317,43 \pm 101,24 ; 366 \pm 79,24 ; 133,74 \pm 116,71)$, játra $(166,36 \pm 59,13 ; 144,1 \pm 24,4 ; 159,45 \pm 72,3 ; 46,2 \pm 28,35)$, myokard $(1,94 \pm 0,93 ; 1,88$ $\pm 0,8 ; 1,35 \pm 0,9 ; 1,61 \pm 1,35)$, bránice $(1,43 \pm 0,74 ; 0,79 \pm 0,6 ; 1,27 \pm 0,89 ; 1,08 \pm 0,98) . \mathrm{V}$ játrech byly zjištěny vysoce signifikantní rozdíly mezi telaty a krávami, býky i jalovicemi. $\mathrm{V}$ ledvinách byly vysoce signifikantní rozdíly v obsahu Cd mezi telaty a býky, jalovicemi a signifikantní rozdíly mezi telaty a krávami. Rovněž byl potvrzen vysoce signifikantní vztah mezi stáŕím krav a obsahem Cd v ledvinách $(\mathrm{r}=0,943)$.

\section{Acknowledgements}

This work was supported by the Grant Agency of the Czech Republic, Project No. 507/95/0531. 


\section{References}

ANDERSEN, O., NIELSEN, J. B. 1994: Effect of simultaneous low - level dietary supplementation with inorganic and organic selenium on whole - body, blood and organ levels of toxic metals in mice. Envir. Hlth. Perspect., Suppl. 3, 102: 321-324

ANDRONIE, I., MITRANESCU, E., ANDRONIE, V. 1994: Plumbum si cadmium in parul de bovine, sol si furaje din zona unei topitorii de neferoase. Lucrari Stiintifice Universitatea de Stiinte Agronomice Bucuresti. Seria C, Med. Vet. 37: 87-90

ANTONIOU, V., TSOUKALI - PAPADOPOULOU, H. 1991: Cadmium concentrations in cattle tissue from animals bred at Sindos area of Thesaloniki. Bull. Hellenic Vet. Med. Soc. 41: 40-43

ARANHA, S., NISHIKAWA, A. M., TAKA, T., SALIONI, E. M. C. 1994: Cadmium and lead levels in bovine livers and kidney in Brazil (abstract). Revta Inst. Adolfo Lutz 1: 16-20

BENCKO, V., CIKRT, M., LENER, J. 1984: Toxické kovy v pracovním a životním prostředí člověka. Avicenum Praha, $264 \mathrm{p}$.

CIBULKA, J. 1986: Pohyb olova, kadmia a rtuti v zemědělské výrobě a biosféré. SZN Praha, 160 p.

DRÁPAL, J., VALCL, O., HONZLOVÁ, A., KREDL, F., PAVELKA, J., ROSMUS, J., ŚEBESTA, J. 1997: Kontaminace potravních řetězcủ cizorodými látkami. Inf. Bull. SVS, 5, 1: 29-45

DOGANOC, D. Z. 1996: Lead and cadmium concentrations in meat, liver and kidney of Slovenian cattle and pigs from 1989 to 1993. Food Addit. Contam. 2: 237-241

FRAZIER, J. M. 1977: Cadmium kinetics in the isolated perfused rat liver: an example of general method for investigating metal metabolism. In: Clinical chemistry and chemical toxicology of metals - Volume 1, S. S: BROWN Ed., Elsevier/ North - Holland Biomedical Press, pp. 33-36

HORKÝ, D., ILLEK, J., PECHOVÁ, A. 1998: Distribution of heavy metals and their ultrahistochemical determination in the organs of calves. Acta vet. Brno 67:51-58

ILLEK, J., DOČEKALOVÁ, H. 1993: Study of the interactions of cadmium and zinc in calves. In: Trace elements in man and animals - TEMA 8, Verlag Media Touristik, Gersdorf, pp. 583-584

KOTTFEROVÁ, J., KORENEKOVÁ, B. 1995: The effect of emissions on heavy metals concentrations in cattle from the area of an industrial plant in Slovakia. Arch. Environ. Contam. Toxicol. 29: 400-405

MORCOMBE, P. W., OETTERSON, D. S., MASTERS, H. G., ROSS, P. J., EDWARDS, J., R. 1994: Cadmium concentrations in kidneys of sheep and cattle in Western Australia. Austr. J. Agric. Res. 45: 851-862

NEATHERY, M. V., MILLER, V. J. 1975: Metabolism and toxicity of $\mathrm{Cd}, \mathrm{Cu}$ and $\mathrm{Pb}$ in animals. J. Dairy Sci. 58: 1777-1781

NOMIYAMA, K., NOMIYAMA, H. 1993: Cadmium-induced renal dysfunction was improved by treating hepatic injury with glycyrrhizin. J. Trace Elem. Exp. Med. 6: 171-178

OHTA, H., SEKI, Y., IMANIYA, S., YOSHIKAWA, H., 1993: Influence of dietary selenium (Se) on chronic cadmium (Cd) toxicity in mice. In: Trace elements in man and animals, ANKE, M., MEISSNER, D., MILLS, C.F., Verlag Media Touristik, pp. 963-965

UNDERWOOD, E. J. 1977: Trace Elements in Human and Animal Nutrition, 4. Ed. New York, Academic Press, $545 \mathrm{p}$.

ZMUDZKI, J., SZKODA, J. 1995: Zawartosc kadmu w tkankach zwierzat i w zywnosci pochodzenia zwierzecego. Med. Pracy 5: $71-81$ 